\title{
Effect of Method of Playing on Passing Accuracy of Football School Players
}

\author{
Emral*, Andre Setiawan \\ Health Physical Education Study Programs And Recreation \\ Faculty of Sport Science \\ Padang State University. \\ *emral_abus@yahoo.co.id
}

\begin{abstract}
The problem in this research is the low level of precision passing. Many factors can increase the precision passing of school football players (SSB) of Bima town of Bukittinggi in between physical condition, exercise, and methods of play. This type of research is quasi-experiment. Thus Spake the purpose of this research is to know the influence of the method of playing against the precision passing of school football players (SSB) of Bima town of Bukittingg. Sampling technique using total sampling. The sample in this research is 10-12 years of age levels (U10-12), that add up to 18 people. Engineering Data collection performed in this study is a test of passing to the wall. Data were analyzed with descriptive statistics and inferential with the formula t-test sample of bound. Based on the results of the data analysis found that there is the influence of the use of methods to increase the ability to play passing football school players (SSB) Bima Bukittinggi.
\end{abstract}

\section{Keywords-method of playing, the accuracy of passing}

\section{INTRODUCTION}

Football is the most popular sport in the world, even this sport worldwide in almost all countries in Europe, Asia, Africa, Australia and the United States. Internationally known as "soccer", football has become the national language as the various nations in the world with a variety of historical and cultural backgrounds, as a means of unifying the world that could go beyond the boundaries of political differences, ethnic and religious.

Nowadays, the development of football in Indonesia is growing quite Football (LPBS) or a football school (SSB) in various regions that represent the development of the game of football. Coaching and sports development achievements implemented gudgeon sports clubs, cultivate and sports coaching, national and regional, and held in stages and sustainable competition [1].

With the SSB LPBS and this becomes an appropriate means to foster and train young players who are skilled football player and achievement. School football (SSB) Bima town of Bukittinggi is one of the institutions that foster education and football training children early age that talent and potential in the game of football. Through coaching and training from an early age can result in great opportunities to perform optimally.

SSB Milky in Bukittinggi, football sports activities run in accordance with a training program that has been created by coach builder activity and SSB, but the improvement of the game has not been widely felt. In 2009 the city of Bukittinggi SSB Milky never won the tournament between SSB se Bukittinggi U-15 and representing the city of Bukittinggi in the Danone Cup Cup U-12.

Based on the observations of researchers from several trials that have been done, in general, SSB player Bima town of Bukittinggi less mastered the basic techniques of football in between passing. Therefore, the game is displayed by players SSB Bima town of Bukittinggi unfavorable. Things most common mistakes made by players SSB Bima town of Bukittinggi is passing.

Researchers looked at the number of players still SSB Bima town of Bukittinggi that have not been able to implement passing technique correctly, so that groove ball was frequently interrupted in the middle line of the game and at the time of passing still less to the point that caused errors in passing.

Factors influencing the passing of which is the position of the body, footstool, perkenaan ball on the feet, the view and then physical condition. For the novice player to be able to play football must be able to perform the movements basic techniques of the game of football. The statement shows that mastering the basic techniques of football is very important for trained [2].

Of the many forms of basic techniques that support the game of football, one of the most important to be possessed by a football athlete is passing ability [10]. For a player is in need once passing to move the ball from one point to another or from one friend to another friend.

Players must be able to measure the slow strong passing performed to a friend so that the ball does not easily picked opponent, and the player must also be able to do the passing idle or running (moving) in the sense of passing of passing silence to silence, rest to move, position move to stationary and moving position to move, therefore, the player must have a good physical condition like: endurance, strength, speed, explosive power, flexibility, balance, coordination, agility, accuracy, reaction in doing the passing.

To obtain a good passing is affected by several factors such as body position at the time of kicking and hold the ball, perkenaan foot with the ball and the view as kicking a ball. In addition, other factors affecting passing 
as internal factors and external factors. Internal factors are innate potential that exists within the athlete's own such as: talent in general (technical and tactical), the psychological aspect (mental play, mental exercise, seriousness in practice, discipline, etc.), physiological aspects (health, nutritional status, muscle fibers, etc.), cognitive intelligence athletes including for example the ability to absorb information and be able to apply. While external factors are factors that come from outside the athletes themselves such as: coaches and their programs, environmental factors, weather factors,

Football School (SSB) Bima Sudirman street address in the District Aur Birugo Tigo Baleh Bukittinggi.Sekolah City Football (SSB) Bima Bukittinggi has a team of football team that was built through exercise activity. Players from these teams consisting of children aged 10 to 16 years. The football team in the Football School (SSB) Bima Bukittinggi practice in the field belongs to the subdistrict Birugo with the frequency of exercise 3 times a week on Wednesdays, Fridays and Sundays.

Football School aims to develop the talents of children in the sport of football, so it is expected that they can excel and become the pride of themselves, family, school, community and nation. School football practice is held three times a week with a planned, continuous, and guided by the trainer.

Football School (SSB) teaches how football is right to emphasize the correct use basic tekhik in this case passing the main point, tactics and strategy to play football so as to achieve the highest achievement.

Passing in the game of football is a way to move the ball to a friend. Based on information from the coach Football School (SSB) Bima Bukittinggi and observations done by researchers at the tournament between (SSB) se bukittinggi, team Football School (SSB) Bima Bukittinggi often make errors in passing that the tactics and strategies that have been in planned by the coaching staff did not go well, the flow of the ball was frequently interrupted only up to the quarterback so the goal is very difficult to create for teams Football School (SSB) Bima Bukittinggi, as evidenced by just three goals from five games that make the football team Football School (SSB ) Milky Bukittinggi cannot get away from the group.

Guided by the above description, it is a problem in this research is the influence of training methods play against passing ability soccer player Football School (SSB) Bima Bukittinggi is not good, so the game is on show at the top of the field and accuracy of passing the ball to the friend intended often poorly targeted. Method of playing is one method of passing effective exercises used to improve the ability of passing [11].

It is not easy for a football player to do passing on target, because the necessary methods proper exercise, training is given in a long time and with the control technique by the coach [3], the method given exercise is done repeatedly, the technical ability of passing can also be improved through the method of play.

Although many factors can affect the accuracy of passing, but on this occasion the author wants to conduct a study related to a method of exercise play against players passing ability Football School (SSB) Bima Bukittinggi.

\section{METHODOLOGY}

This type of research is a quasi-experimental (quasiexperimental research) [4]. The basis of this method uses is where experimentation is a research technique based on experiments with testing beginning and end of the test. This study aimed to find the influence of training methods play against the passing ability of players in Football School (SSB) Bima Bukittinggi.

This study dilakasanakan place on the football field Aur village Birugo Birugo Tigo Baleh District of Bukittinggi, where the player Football School (SSB) Bima Bukittinggi exercise and the time the research was conducted, ie on 6 August to 19 September 2018.

\section{RESULT}

Passing the test based on the results given there are differences in the average value (mean) obtained in the initial tests before being given treatment method of play is equal at 62.33 and after being given a treatment derived average value (mean) of 67.22. This means that there increasing by 4.89 , with a value of $\mathrm{t}$ analysis or by $2.87 \mathrm{t}$ greater than $t$ table value of 2.11. Detailed data is shown in Table 1.

Table 1. Data from passing ability

\begin{tabular}{|c|c|c|}
\hline & Pre-test & Post-test \\
\hline Average & 62.33 & 67.22 \\
\hline $\mathbf{N}$ & 30 & 30 \\
\hline t - count & \multicolumn{2}{|c|}{2.87} \\
\hline t table & 2.11 \\
\hline df & 28 \\
\hline
\end{tabular}

\section{DISCUSSION}

Based on the results of testing the hypothesis in research, it is found the results stated and proved that the method of play can influence the accuracy of the player passing football school (SSB) Bima City Bukittinggi.Dengan so may mean that one effort that can be done to improve the precision passing in the game of football is the method of play. It is known from the difference in the average value (mean) obtained in the initial tests before being given treatment method of play is equal for $62,33 \mathrm{dan}$ after being given a treatment derived average value (mean) of 67.22. This means that there increasing by 4.89 , with a value of $\mathrm{t}$ analysis or by $2.87 \mathrm{t}$ greater than $t$ table value of 2.11 .

One important technique in the game of football that must be controlled by the game due to a football is a passing technique (pass) is to move the ball from one player to another player. In passing train, we must concentrate on our passing the ball straight and the direction that we want [5]. Thus it can be interpreted that a football player must be able to provide precise target diinginkan.Ketepatan oper is a factor that needed someone to achieve the desired targets. 
The accuracy is a factor that takes one to give directions to someone with the intent and purpose tertentu.Sehingga ball cannot be seized or move to the opponent. In order for the ball on target to friends who are heading, the player must have the technical skills to better.In the passing of this research to improve the precision of passing technique performed by the method of play, which is defined as the technique is a means used or developed by a person or athlete to complete / solve a movement task in the sport effectively and efficiently. The task of the movement in question is a form of action or actions performed motor movement soccer player in achieving a goal that is a series of movements passing movement or pass the ball in temansatu team.

Furthermore, passing may also be defined as art momentum move the ball from one player to another player [7]. Passing is best accomplished by using the legs, but other body parts can also be used. Passing requires a lot of engineering many of the techniques is very important to keep possession of the ball. Compared with other basic techniques, passing more done in playing football, so that it becomes more reason why teknikpassing given for example by the method of play. All forms of play were given during the 16 sessions it can give a significant influence on the accuracy of the Milky SSB soccer player passing Bukittinggi.

In the game of football technique of passing can be done in various ways, among others, is passing on legs inside, using a foot outside and passing using the backs of shoes, usually do passing this way is at a greater distance with the ball bounced to the top [6]. Furthermore, the passing can also be done by caradrop pass, passing it given to teammates in the back, and is very beneficial because it can create space and also dispersed opponents guard.

Furthermore, in doing passing that must be considered is the implementation process such as body position, location of the foot, pedestal when kicking, perkenaan foot with the ball, the point of weight gain, outlook, power kick, and follow thourgh (continued movement). The implementation process in order to obtain a passing kick as desired generally the same as the following: "1) The location of the foot of the pedestal at the time of kicking. 2) perkenaan foot on the ball. 3) perkenaan the ball on the leg. 4) The point of weight. 5) Strength and follow throw [8].

In addition to the implementation of the method or process of passing as described above, there are other factors that should be considered in passing that the passing on target. Among these factors are some of the components of a physical condition such as leg muscle strength because it is important in determining how the desired speed of the ball. Then the components of flexibility (flexibility) is the effectiveness of a person in conformity to all the activities with wide body stretching, accuracy (accuracy) is a person's ability to control movements, independent of a target [9].

\section{CONCLUSION}

Based on the results of data analysis, research and discussion that has been described previously, it can be concluded that: There is the influence of the use of methods to increase the ability to play passing football school players (SSB) Bima Bukittinggi.

\section{REFERENCES}

[1[ Undang - Undang Republik Indonesia Nomor 3 Tahun 2005 Tentang Pembinaan dan Pengembangan Olahraga Prestasi. Jakarta: BP. Cipta Jaya. 2006.pp.23-44

[2] Arsil \& Yulifri. "Permainan Sepakbola". Padang: Fakultas Ilmu Keolahragaan Universitas Negeri Padang. 2011.pp. 45-48

[3] Bompa, Tudor O, "Theroy and Methodology of Training”. Kendal. Iowa: Hunt Publishing Company, 1994. pp.70-88

[4] Sugiyono. "Metode penelitian kuantitatif kualitatif dan R \& D". Bandung: Alfabeta. 2010.pp.34-55

[5] R. Koger. "Latihan Andal Sepakbola Remaja”. Kantor Kementrian Pemuda dan Olahraga . 2007. pp. 20-30

[6] Emral Abus. "Buku Ajar Sepakbola”. Padang. FIK UNP. 2005.pp. 776-80

[7] Mielke, Danny. "Dasar-Dasar Sepakbola”. Bandung. PT. Intan Sejati. 2007.pp.44-66

[8] Luxbacer, Joseph A. "Sepak bola (EdisiKedua)". Jakarta: Raja Grafindo Persada. 2004.pp. 21-27

[9] Bafirman. "Fisiologi Olahraga". Padang: Wineka Media. 2013.pp.33-36

[10] Yulifri, A. Asmi. "Pengaruh Metode Rangkaian Bermain Dan Rangkaian Latihan Terhadap Keterampilan Bermain Sepakbola”. Padang: FIK UNP. 2017.pp. 21-26

[11] H. Rustanto. "Upaya Meningkatan Keterampilan Passing Sepakbola Dengan Kaki Bagian Dalam Menggunakan Metode Bermain”. J. Pendidikan Olahraga, Vol. 6 No.1, pp 21-32. Juni 2017. 